\title{
A STUDY OF REGULATORY INTERVENTION IN LABOR-MANAGEMENT RELATIONS: SCHOOL DESEGREGATION IN LOS ANGELES, DADE COUNTY, AND BOSTON*
}

\author{
HARRY C. KATZ
}

Associate Professor of Industrial Relations

Alfred P. Sloan School of Management

Massachusetts Institute of Technology

\begin{abstract}
This article analyzes the interaction between public school desegregation and labor relations in Los Angeles, Dade County, and Boston. First enumerating the ways in which desegregation led to specific changes in either personnel policies or collective bargaining agreements in the three school systems, then providing an evaluation of the performance of the court's regulatory in tervention within labor-management relations in the three school systems. After comparing regulatory performance, the factors that influence the observed variations in performance are assessed. A distinction is found between those causal factors that are "environmental" and those that are under the direct control of the parties. The article concludes with a theoretical discussion of the differences that exist between the court's regulatory intervention in collective bargaining and arbitration.
\end{abstract}

\section{INTRODUCTION}

The 1970's have witnessed an increase in regulatory intervention where either legislative agencies or courts operate as an intervening party within labormanagement relations. Prominent examples of this sort of regulatory intervention include equal employment opportunity and occupational safety and health. This paper analyzes another case--the federal court's effort to influence the relations between teachers, school administrators, and community groups as part

*This research was supported by grant \#80-0184 from the National Institute of Education, U.S. Department of Education. 
of school desegregation. Specifically, events in Los Angeles, Dade County (Florida), and Boston are examined. School desegregation has rarely been analyzed in this way. As a result, one of the tasks of this article is enumeration of the ways in which desegregation led to specific changes in either personnel policies or collective bargaining agreements in the three school systems.

Another task of this article is evaluation of the performance of the court's regulatory intervention within labor-management relations in the three school systems. Much criticism has surrounded other instances of regulatory intervention within collective bargaining [1]. One criticism frequently made is that the process suffers because the regulator ignores both the concerns and talents of the parties whose actions are being regulated. Instead, the parties spend much of their time and energy fighting one another and little attention is paid to the search for solutions to existing problems. A recommendation commonly made to improve such regulation is that more cooperation occur between the parties. It is said that the third party, be it a court or an administrative agency, should consult more extensively with the regulated parties and rely more heavily on their expertise. But, what can be done to facilitate this sort of cooperation? And, what are some of the factors that impede cooperation? Here, much of the criticism of regulation has had little to offer.

This article tries to remedy this deficiency of past research. After comparing regulatory performance in the three school systems, the factors that influenced the observed variations in performance are assessed. A useful distinction can be drawn between factors that are "environmental" and those under the direct control of the parties. With those causal factors in mind, the article concludes with a discussion of the differences that exist between the court's regulatory intervention in collective bargaining and grievance or interest arbitration, a more traditional form of intervention in collective bargaining.

\section{EXPERIENCES IN THE THREE SCHOOL SYSTEMS}

The case studies that follow are not exhaustive. ${ }^{1}$ The intent is to present a general overview of the experiences within each school system and highlight the aspects of each case that illustrate the major themes of the article.

\section{Los Angeles}

In Los Angeles, the United Teachers of Los Angeles (UTLA) and the school administration made a number of modifications to the district's personnel policies and collective bargaining agreement as part of school desegregation, including:

\footnotetext{
${ }^{1}$ This article is part of a larger research project [2]. For other research that discusses the interaction between labor relations and desegregation see reference [3].
} 
- a voluntary teacher transfer program with "return rights" used to facilitate faculty integration across schools in the district;

- a modified seniority transfer program used when teachers move with students reassigned as part of student integration;

- an Urban Classroom Teachers Program that provides an 11 percent salary premium to teachers who voluntarily transfer to urban core schools;

- a bilingual incentive pay program that pays an 11 percent salary premium to teachers of bilingual education in select schools.

These and other personnel policies originated in court-directed hearings that evolved into consultative planning sessions. The consultative sessions were multipartite and typically involved the federal court (Judge Paul Egly), the school board and administration, the UTLA, the plaintiffs in the original desegregation suit, and citizen groups such as BUS-STOP (a group opposed to mandatory busing).

An example of this consultative process is provided in the evolution of the Urban Classroom Teachers Program. Staffing schools in core urban areas was a perennial problem in the Los Angeles system. Those schools had a higher than average faculty turnover rate as, upon accumulating seniority in core schools, teachers often transferred to schools in more affluent neighborhoods. That staffing problem was exacerbated by the district's faculty integration program, which initiated the transfer of a substantial number of black faculty out of the core urban schools.

Judge Egly concluded that an incentive pay scheme would be one way to improve the educational process in the district's urban core schools. The judge encouraged the school administration, the teachers' union, and community groups to design such a scheme [4]. After extensive debate, the UTLA and the school administration returned to the court with the agreed-upon Urban Classroom Teachers Program. To overcome the union's initial opposition to the existence of a pay differential, the court agreed to fund the 11 percent salary premium included in the program out of a desegregation budget provided to the court by the California State Legislature.

The Urban Classroom Teachers Program (UCTP) reflects the competing demands that had arisen in the multipartite bargaining surrounding the program's development. Teachers in the program are required to perform additional duties that amount to two to three hours of service per week, including such activities as counseling students after regular school hours. As part of the program, teachers also engage in five days of staff development (with additional compensation). The program is described in the court's desegregation order and is outlined in the union's collective bargaining agreement [5]. As stipulated in the collected bargaining agreement, the UTLA accepts the program only as long as it is funded by the court. 
The main advantage of the UCTP from the viewpoint of the school administration was that it helped faculty recruitment in the core urban schools. The district has been able to completely avoid mandatory teacher transfers after the creation of UCTP. In addition, the administration saw the UCTP as a way to clarify and strengthen teacher work requirements within those schools. Principals were strongly in favor of the provisions within UCTP that outlined specific additional duties required of teachers. ${ }^{2}$

The UTLA was enticed by the court's provision of additional salary funding. From the union's viewpoint, the other advantage of the program was that it reduced the demand for the kind of mandatory transfers that preceded the UCTP. The inclusion of the UCTP in the collective bargaining agreement also gave teachers recourse to the grievance procedure outlined in that agreement as a mechanism by which disputes over the implementation of the UCTP could be resolved.

The key to the development of these creative solutions in Los Angeles was the consultative process that brought together the court, the union, the school administration, and community representatives. Through both formal and informal discussions, Judge Egly provided a forum in which the affected parties could meet and discuss their concerns. At the same time, the court has retained final decision-making authority. Consultation has been provided without eroding the court's ability to make judgments that do not completely satisfy one or more of the affected parties.

The existence of a consultative process in Los Angeles has not eliminated conflicts between the affected parties. For example, the plantiffs to the desegregation suit and the UTLA have often disagreed. The plaintiffs opposed the union's original petition to intervene in the case, and the plaintiffs continue to be unhappy with the use of seniority and pay differentials in the UCTP. ${ }^{3}$ Nor has there always been agreement between the teachers' union and the school administration. The union prefers strict adherence to seniority, while the administration seeks to create a greater degree of flexibility within teacher transfer procedures. The point is that although disagreements remain, the parties in Los Angeles have been able to effectively utilize their own expertise to design solutions to many of the problems that have arisen in the desegregation process. And further, when the parties do not agree, the consultative process produces mechanisms by which the parties clarify their points of agreement and disagreement. An example of the latter is the "Joint Status Report" in which the UTLA and the school administration outlined their views regarding a bilingual incentive pay scheme [8].

\footnotetext{
${ }^{2}$ These and other viewpoints of the school administration and the teachers' union were gathered during interviews in January 1981 with members of the Deputy Superintendent's Office for Staff Relations, Los Angeles Unified School District, and the executive officers of the UTLA.

${ }^{3}$ The plaintiffs opposed the salary differential as a form of "combat pay." [6]
} 


\section{Dade County, Florida}

The desegregation process in Dade County also has involved a substantial amount of consultation and accommodation between the court and teachers. This was particularly true in the early stages of the desegregation case in Dade County. During the early phase the teachers' representative, the Classroom Teachers Association (CTA), supported the integration process and participated actively with the Florida Desegregation Center in the design of the desegregation plan. In fact, the CTA had supported integration of the Dade schools prior to federal court involvement. The CTA's support for integration came in 1962 in the aftermath of the association's formation by way of a merger of two segregated teachers' association that had existed as part of Dade's segregated dual school system [9]. This merger created the first integrated teacher organization south of the Mason-Dixon Line.

Cooperation between the federal court and the Classroom Teachers Association took many forms. The court followed a CTA recommendation and ordered that any mandatory teacher transfers required as part of faculty integration follow seniority. The CTA went on to encourage voluntary teacher transfers during students integration, with the president of the association taking the lead by volunteering to be reassigned to teach in one of Dade's innercity schools and thereby give up the prerogatives of union office.

The accommodative spirit initiated in the early phase of desegregation in Dade continued during the discussions carried out by the school administration and teachers as part of their later collective bargaining relationship. Faculty racial guidelines with a transfer system and hardship appeals board now appear as part of the teachers' collective bargaining agreement [10] .

\section{Boston}

The spirit of compromise that characterizes the response to desegregation by teacher unions in Los Angeles and Dade County is in marked contrast to the experience in Boston. From the start, the teachers' union in Boston adamantly protested the initiation of court-order desegregation. The union, like many teachers in the school system, was unsympathetic to charges that the school system was blatantly discriminatory and required major restructuring to set it right. In addition, the Boston Teacher Union (BTU) argued that reorganization of the school system would be "too educationally disruptive." [11]

The BTU was particularly upset about the large number of teacher transfers and reassignments that were produced by desegregation. These transfers and reassignments followed the creation of new schools, the closing of a number of schools, and the large-scale reorganizations of within-school programs, which were all part of the desegregation plan. To facilitate those transfers, the court felt it necessary to overrule existing language in the collective bargaining agreement that existed between the Boston School Committee and the teachers' union. 
The court (Judge W. Arthur Garrity) argued that both the speed and the magnitude of teacher transfers precluded the use of the elaborate bidding and rating transfer procedures outlined in the collective bargaining agreement.

The clash between the teachers' union and the court regarding transfer rights came to typify the desegregation process in Boston. Although Judge Garrity regularly has conducted hearings that brought the various affected parties together, those hearings rarely have produced problem-solving activities. A reflection of the lack of cooperation is the BTU's painstaking, though futile, efforts to maintain a separation between collective bargaining and the desegregation process. Those efforts are illustrated by the absence of any explicit language in the teachers' collective bargaining agreement concerning desegregation or its consequences. Yet, the federal court's desegregation orders have led to frequent modifications of the school district's personnel policies which, in turn, have led to changes in the policies of the BTU. A poignant example is provided by minority faculty hiring, the issue that came to dominate the Boston desegregation case in the late 1970's and early 1980's.

In his original desegregation orders, Judge Garrity concluded that one aspect of segregation in the Boston school system was the limited presence of blacks on the school faculty. The judge set a goal that 20 percent of all teachers in the Boston system should be black and ordered the immediate hiring of 280 new, permanent, black teachers [12]. The 20 percent figure was equal to the fraction of the total population of Boston that was black, according to the 1970 census. Prior to the court's orders (1973), the percentage of black teachers in the Boston system had been 7.1 percent. Throughout the late 1970's, Judge Garrity issue amended "hiring orders" in response to the school system's slow progress in meeting the court's 20 percent goal and a number of other complications.

One of the complications the court had to wrestle with was a change in the school department's hiring policy. From 1975 on, the school department continued to hire a number of new teachers, but only on a provisional basis (one-year contracts), and it discontinued hiring teachers on a permanent, contractual basis. The motives behind this policy switch and the court's response to that change in policy are rather complicated. What is clear is that this switch in policy limited the magnitude of minority hiring and frustrated the intent of the court's minority hiring goal.

Another complication during the 1980-81 school year made the court choose between continuing affirmative action in minority hiring and preserving the seniority rights of existing faculty. That choice was created by pressures placed on the Boston school administration to reduce the total number of teachers in the systern. A primary source of that pressure was the massive decline in enrollment that has occurred in the Boston system. In 1965 total enrollment in the school system stood at 94,035 . Enrollment climbed to 97,344 in 1970 and then declined to 84,988 in 1975 and by January, 1981, stood at 64,481 . If class size had been kept constant at the level of twenty-five students per class 
and teacher workloads remained constant, the drop in enrollment of 32,863 that occurred between 1970 and 1981 would have facilitated a potential reduction of 1315 teachers (or 25\% of the total number of teachers in 1973-74). In fact, the total number of teachers in the system has remained constant throughout the 1970s. ${ }^{4}$ However, the 1981 passage of Proposition $2 \frac{1}{2}$ in a statewide general election has created the prospect of substantial reductions in Boston's municipal revenue sources.

The Boston School Committee voted to lay off 960 teachers at the start of the fall 1981 term. ${ }^{5}$ The question that came before the court was how to allocate those reductions in the number of teachers. If teacher workforce reductions occur according to seniority, the number and percentage of black teachers in the system will drop significantly since most of the black teachers were hired after 1973, the start of the desegregation case. For example, if the school department were to carry out its layoff of 960 teachers according to strict seniority, the percentage of black teachers in the system would drop from 19 to 8 percent.

In light of the effects of layoff by seniority, Judge Garrity ordered teacher layoffs to be performed in such a way that the systemwide percentage of black teachers remain at the existing level of 19 percent [13]. The judge also required that black teachers receive an absolute preference for recall until a 20 percent figure is reached and after that point, no fewer than 20 percent of the teachers subsequently recalled or recruited be black. The school committee has agreed to follow the court's orders when implementing teacher layoffs.

The Boston Teachers Union actively participated in the debate that surrounded the court's efforts to increase minority faculty representation. Early on, the BTU unsuccessfully appealed Judge Garrity's 20 percent hiring order [14]. Later, the union adamantly expressed its opposition to "any plan which gives preferential treatment to black provisional teachers." [15].

When reviewing the course of relations in the 1970's between the BTU and the school department, it might at first seem surprising to learn that the BTU did not adamantly resist the increased hiring of provisional teachers and the halt in the hiring of new permanent teachers. No union likes the wage and benefit reductions that accompanied the shift from permanent to provisional contracts, and one might have expected the BTU to firmly resist the change in the school department's hiring policy. In fact, it can be argued that the BTU took a number of steps to exacerbate differences between permanent and provisional teachers, including its negotiation of a job-security agreement with a no-layoff clause that covers only permanent teachers.

Part of the union's motivation for the exclusion of provisional teachers from coverage by the no-layoff clause stems from the fact that provisional teachers

\footnotetext{
${ }^{4}$ The number of teachers in the Boston school system was 5214 in 1973-74 and 5150 as of March, 1981.

${ }^{5}$ In March, 1981, 117 provisional teachers were laid off in a manner that preserved the existing percen tage of black teachers.
} 
tend to staff expanding program areas such as bilingual education, while permanent teachers generally staff shrinking "regular education" programs. ${ }^{6}$ In the face of the district's policy of laying off by certification area, the exclusion of provisional teachers from coverage by the no-layoff clause was necessary to protect the job security of senior, permanent teachers certified in the shrinking regular education area.

With respect to the imminent layoffs, the BTU has firmly held to the position that any teacher layoffs follow the seniority provisions outlined in the union's contract [16]. The union has initiated court appeals of both the school department's plans for layoffs and Judge Garrity's orders to override seniority provisions if layoffs do occur.

\section{FACTORS THAT CONTRIBUTED TO THE VARIATIONS IN REGULATORY PERFORMANCE}

When comparing experiences of the three school systems, two criteria stand out as indicators of the quality of the regulatory intervention. One criterion is the teacher union's attitude toward third-party intervention. In both Los Angeles and Dade County, the unions accepted and, in some instances, strongly supported the court's desegregation goals. However, in Boston, throughout the desegregation process the teachers' union remained antagonistic toward court intervention.

A second criterion is the extent to which the union participates with the court, the school administration, and community groups in problem-solving activities. Here, as well, the Los Angeles and Dade systems are superior to Boston. The Los Angeles and Dade County public schools have devised a larger number and wider range of problem-solving activities as part of the desegregation process when compared to Boston.

What caused these differences in the performance of the court's regulatory intervention in labor relations in the three school systems? My answer to this question requires that a distinction be made between two broad categories of causal factors. One set of causal factors can be called environmental variables, because each was largely not under the control of the parties once the desegregation process began. These environmental factors include the racial composition of the faculty at the time desegregation began; whether or not the teachers had formal bargaining rights at the time desegregation was started; and the economic conditions that prevailed in the school system during desegregation.

Black teachers were a significant political force in support of desegregation in Los Angeles and Dade County. In both, when the desegregation process began there was already a sizable number of black teachers in the school system.

\footnotetext{
${ }^{6}$ For example, as of March 1981, provisional teachers comprised 43 percent of all bilingual teachers while only 7 percent of all regular education teachers in the system were on provisional status.
} 
Black teachers comprised roughly 18 percent of the full-time teachers in both of these systems at the start of desegregation [17]. In Boston, in contrast, black teachers represented only 7 percent of the teacher workforce at the time desegregation began.

But the number of black teachers is not the only important influence. Black teachers were a significant political force within the Dade County school system not only because their numbers were large. The merger of black and white teacher associations that had preceded the start of desegregation in Dade was a critical factor in shaping the accommodative stance taken by Dade teachers toward integration.

The accommodative stance toward desegregation taken by teachers' ?nions in Los Angeles and Dade County also was encouraged by the fact that in those systems desegregation occurred at a time when the teachers' union lacked formal collective bargaining rights. In both cases, state laws did not then grant bargaining rights to local public school teachers. Deprived of formal bargaining rights, participation in a consultative relationship with the federal court during desegregation was important to the teachers' unions for two reasons. First, participation satisfied some of the unions' unfulfilled demands to be involved in school decision making. Second, the unions used their participation with the court to strengthen their demands for full collective bargaining rights. In Los Angeles and Dade County, the teachers' unions went to the public with appeals that their involvement in desegregation illustrated their responsibility and entitled them to more extensive collective bargaining privileges. ${ }^{\text {? }}$

That was not the case in Boston where by the time desegregation started (1973), the teachers' union already possessed full collective rights and had signed formal contracts for eight years. In Boston, the teachers' union knew that it could affect decisions through the collective bargaining process. The security provided by their collective bargaining agreement in a sense gave the Boston Teachers Union the freedom to engage in a combative relationship with the federal court.

The point is not that collective bargaining is a hinderance to accommodation during desegregation. Rather, my claim is that a firmly entrenched system of collective bargaining may provide a teachers' union with an inclination to resist the beginning of regulatory intervention in labor-management relations.

Another environmental factor that shaped the response to desegregation in all three school systems was the economic situation. In Boston, the economic environment produced an atmosphere of contraction that made problem solving and the search for areas of joint gain difficult. A contractionary environment was produced in Boston by massive declines in enrollment. Consequently, there always existed a threat that the school committee would respond to these enrollment declines by laying off a substantial number of teachers. In response

${ }^{7}$ These appeals show up repeatedly in newspapers and minutes of city council meetings in both cities. 
to that threat, the BTU was extremely protective of the rights of senior teachers and resistant to policies that might even slightly erode the job security of the senior teachers.

In Los Angeles and Dade County, enrollment trends did not create a contractionary environment. Enrollments were expanding in the aftermath of the start of desegregation in Dade County. ${ }^{3}$ As a result, even though the system was not under a court order to do so, it was relatively easy for the Dade system to expand employment opportunities for minorities. Enrollments in Los Angeles schools have been declining during desegregation, al though not nearly on the scale of the decline in Boston. ${ }^{9} \quad$ Over this same time period the number of full-time teachers in the Los Angeles system has remained constant.

One could then argue that the contrasting economic environments within the three school systems set the tone for regulatory performance in these three school systems. There are, however, a number of issues that call into question the simple notion that the economic environment was a determinant causal factor. First, as mentioned earlier, until the spring of 1981 the Boston Teachers Union did not actually face layoffs. Enrollments may have been declining massively over the 1970s, but the number of teachers in the system was not reduced through layoffs. Second, even in the face of declining enrollments, there were a number of potential areas of agreement between the federal court and the BTU around which problem solving could have occurred. These included the court's success in assuring full funding for the school year in 1976 and the limitations imposed by the court on the school committee's attempt to close schools in $1979 .^{10}$ Furthermore, in the early phases of desegregation in Boston, there were a number of other potential agreements that could have been forged between the court and the teachers' union. The parties could have arranged some sort of orderly teacher transfer mechanism as was used in Los Angeles and Dade County. Likewise, the court, the teachers' union, and the school administration could have fashioned mechanisms to increase minority hiring without having to hire minority teachers on a provisional contract basis. The question that remains is why the parties so rarely took advantage of the potential areas of joint gain that did arise during the desegregation process in Boston.

Part of the explanation lies in steps taken by the parties during the desegregation process. Particular actions that spurred compromise in Los Angeles and Dade include the use of incentives to create the possibility of joint gain; the extent to which agreement was reached early on; and the degree

\footnotetext{
${ }^{8}$ Dade County school enrollments climbed from 233,222 in 1968 (the year desegregation started) to 246,534 in 1974 . Over the same period the number of full-time teachers increased from 9482 to 11,635 .

${ }^{9}$ Enrollments in the Los Angeles school system declined from 613,460 in 1975 to 542,482 in 1979.

${ }^{10}$ These events are discussed in more de tail in reference [18].
} 
to which there was formal integration of collective bargaining and courtdirected activities. These actions, in contrast to the environmental factors discussed above, were under the direct control of the parties.

Although the economic environment within each school system was important because it influenced the extent to which situations arose where one party had to lose, to some degree the parties themselves could create expansionary environments. An example is provided in Los Angeles where the court's use of the state's desegregation budget was used to encourage compromise. Money from that state budget functioned as a "carrot" that enticed the UTLA to accept the Urban Teachers Classroom Program. State payment of the salary differential within the UCTP thereby created a bargaining situation in which both the court and the teachers' union could gain. With the possibility of joint gain, it was much easier for the parties to reach agreement on some of the more contentious issues surrounding the UCTP.

The involvement of the UTLA in the design of the Urban Classroom Teachers Program set a positive tone that facilitated the discussion of problems that arose later in the Los Angeles desegregation process. In that way, the manipulation of state funding had the long-run effect of encouraging cooperative bargaining as well as solving some of the district's short-run teacher transfer problems.

In Dade County, it was agreement reached early on regarding the faculty integration program that set the tone for a cooperative relationship. There, the court's provision of seniority rights as part of mandatory transfers in the teacher integration program facilitated both teachers' acceptance of mandatory transfers and encouraged the union's active support of voluntary teacher transfers. The union's involvement in the implementation of teacher transfers then facilitated reconciliation during the later phases of Dade's desegregation plan.

In contrast, the lack of early agreement in the Boston system created a noncooperative atmosphere. By failing to reach agreement in the early stages of desegregation when the economic environment was more favorable, the parties in Boston were further handicapped in their efforts to cope with the difficult conditions that arose later on in Boston. The contractionary fiscal environment that developed in Boston in 1981 would have been difficult to handle even if the parties had approached those problems with the background of a good working relationship.

In both Los Angeles and Dade County, parts of the desegregation program and agreed-upon modifications on personnel policies are spelled out in the teacher union's collective bargaining agreement. Inclusion within the collective bargaining agreement signalled formal acceptance by the union of these desegregation programs. And, the integration of collective bargaining and courtdirected programs eased adjustment to the desegregation process. By describing the programs in the contract, the union and the school administration could rely on the contract's grievance procedure to adjudicate disagreements that arose over the implementation of these policies. 
In Boston, the absence of any coniract language concerning the desegregation program was a signal of the union's disagreement with much of that program and furthermore, operated as a continuing source of confusion. For instance, without contract language concerning issues such as faculty integration, the jurisdiction of disputes over that issue remained unclear. The circumstances surrounding a grievance that arose in Boston illustrates that confusion. The Boston Teachers' Union at one point filed a grievance concerning the implementation of the court's racial balance guidelines. The arbitrator hearing the case was at a loss as to how to rule on the grievance and appealed to Judge Garrity for a clarifying ruling. The judge issued a ruling and sent the grievance case back to the arbitrator. The existence of contract language regarding faculty integration might not have prevented the grievance from arising but at least it would have sped up the process and avoided shuffling the case between the court and the arbitrator.

It could be argued that a cooperative relationship did not emerge among the federal court, the school administration, and the Boston Teachers Union because of the level of citizen opposition toward desegregation and busing that prevailed in Boston. There was a lot of citizen opposition to desegregation in Boston, but it should be recognized that similar opposition existed in Los Angeles. By 1979, the Los Angeles school board was dominated by individuals who opposed busing. Furthermore, one of the most active community groups in the Los Angeles area was BUS-STOP, a group opposed to busing and Judge Egly's desegregation orders. ${ }^{11}$ Nor was the end of the dual school system readily accepted by all of the Miami community. Yet, in Dade County and Los Angeles the parties involved in the labor-management relationship were able to create a cooperative relationship that was separated from surrounding community opposition to desegregation.

It is more difficult to assess the impact of the various political environments that surrounded the three school systems. In many ways the combative relationships that prevailed in Boston during desegregation are representative of the style of Massachusetts politics. That style is characterized by acrimonious fights between the parties involved in any political decision and the postponement of realistic decision making until the arrival of a crisis point. Rarely does patient problem solving occur as part of that mode of governance. Illustrations of this process are provided in the recent financial crises within the Massachusetts Bay Transit Authority, the Boston city government, and the Massachusetts state government. For the court, the Boston Teachers Union, the school administration, and community groups to have forged a cooperative relationship would have required that the parties break out of that pattern.

${ }^{11}$ The course of school desegregation in Los Angeles was altered abruptly in the spring of 1981 when the California Supreme Court let stand Proposition 1, an initiative approved by California voters. That ini tiative prohibits court-ordered busing unless (unlike in Los Angeles) it was initiated to correct intentional segregation. At this time, it is unclear how, if at all, the end of mandatory busing will affect labor relations in the Los Angeles schools. 
The parties in the Los Angeles school system, on the other hand, had the benefit of operating in a state noted for its reform style of government. One would expect that a number of the features of that reform style, such as a greater emphasis on planning, would facilitate a more cooperative response to regulatory intervention. Yet, much cooperation occurred in Dade County where the style of politics is not of the California reform mode. As in the case of the economic environment, I am led to the conclusion that the political environment is an influential but not a determining causal factor.

At a time when the two leading national teacher organizations are competing actively in representation elections throughout the country, it is important to consider the impact of the policies of those national organizations on the desegregation process. This sample does contain a mix of national affiliations. In Dade County the Classroom Teachers Association was affiliated with the National Education Association throughout the 1960's. However, when the Classroom Teachers Association gained full bargaining rights in 1974, its affiliation shifted to the American Federation of Teachers. The Boston Teachers Union has remained affiliated with the AFT since the local union's inception in 1965. In Los Angeles, since 1974 the United Teachers has maintained a form of dual affiliation where individuals within the UTLA are free to join either the AFT or the NEA, and the UTLA itself maintains no formal affiliation with any national teachers' union.

It is my conclusion, however, that the national policies of the AFT and the NEA had no substantive impact on the conduct of union policies with respect to desegregation in the three school systems under study. The policies developed by the teachers' unions in the three systems were influenced by political pressures within the local unions, teacher attitudes, and community pressures, but not by the national teacher organizations.

\section{HOW REGULATORY INTERVENTION DIFFERS FROM ARBITRATION}

This study reveals some of the difficulties the federal court faced in its role as a regulator of labor-management relations. Many of the court's problems derive from the fact that the court had to perform two functions. On the one hand, the court operated as an enforcer of orders that at times were perceived to be distasteful to both management and labor. In addition, the court was trying to encourage the participation and cooperation of labor and management in the design of the desegregation plan. When attempting to satisfy these roles the court could adopt elements of the mode of operation utilized by grievance or interest arbitrators, but in some ways the court had to forge a role that superseded either of those models.

During the desegregation process in the three school systems, the court at times had to operate as an enforcement agency because parts of the court's desegregation orders were opposed by labor and management. An example is 
provided in the dispute concerning minority faculty hiring in Boston. There, at the start of school desegregation, both the school administration and the teacher's union opposed the court's efforts to increase the representation of blacks within the school faculty. As this study shows, the opposition to the court's hiring orders included subtle maneuvers such as the shift to the employment of provisional status teachers. In this role of an enforcer of orders that both labor and management opposed, the court operated in a capacity that is not common to either grievance or interest arbitration. An arbitrator, in contrast, typically is in the position of compromising the demands of labor and management.

The desegregation process also contains instances in which the participation of labor and management in the design of third-party orders provides benefits, as is the situation frequently during grievance and interest arbitration. The Urban Classroom Teachers Program in Los Angeles is an example of a creative problem-solving activity whose design required the expertise and involvement of the affected parties. The often-stated dictum that labor and management work better with policies they help to design is strongly supported by the experiences in these three school systems.

The difficult issue is how the regulating party can encourage participation while at the same time administering distasteful regulations. The experiences in Los Angeles and Dade County do suggest some tactics that could be utilized to encourage cooperation. These include the manipulation of financial incentives to provide situations of joint gain. Furthermore, events in these two cities suggest the value of informal multipartite discussions and early agreement in the regulatory process. Yet, there may be no simple answer as to how regulatory intervention can balance its two roles. At a time when regulatory intervention within collective bargaining in the public and private sectors is on the rise, this is a problem worthy of more extensive consideration.

\section{ACKNOWLEDGEMENTS}

The author gratefully acknowledges helpful comments on earlier drafts of this paper from Thomas Kochan, Robert McKersie, Charles Myers and Paul Osterman. The views expressed herin are solely those of the author.

\section{REFERENCES}

1. J. T. D unlop, The Limits of Legal Compulsion, Labor Law Journal, 27:2, pp. 67-74, February 1976.

2. H. C. Katz, Labor Relations and Public School Desegregation in Los Angeles, Dade County, and Boston, report to the National Institute of Education, U.S. Department of Education, 1981. 
3. B. Bosma, Planning for and Implementing Effective School Desegregation: The Role of Teacher Associations, National Institute of Education, November 1980.

4. Racially Isolated Minority Schools Order, Judge Paul Egly, Superior Court of the State of California for the County of Los Angeles, Crawford $v s$. Board of Education of the City of Los Angeles, June 21, 1979.

5. 1979-80 Agreement-Los Angeles Unified School District and United Teachers of Los Angeles, Article XI-A, pp. 42-46.

6. Petitioners Proposed Program of Assistance to Minority Segregated Schools for September 1980, Mary Ellen Crawford et al. petitioners, submitted to Superior Court of the State of California, August 6, 1980.

7. D. Rogers, 110 Livingston Street, Random House, New York, p. 196, 1968.

8. "Collective Bargaining Issues Related to Overcrowded Schools, Class Size, and to English Use Limitations, (NES/LES)," Joint Status Report by Los Angeles Unified School District and United Teachers-Los Angeles, August 19, 1980.

9. "Official CTA Background and Fact Bulletin on School Desegregation," Dade County Teacher, p. 5, February 1970.

10. "Contract Between the Dade County Public Schools and the United Teachers of Dade, September 1977-October 1980," Addendum, pp. 54-59.

11. See the desegregation story in The Boston Union Teacher, p. 1, March 1974.

12. "Order on Hiring," Judge W. Arthur Garrity, U. S. District Court of Massachusetts, July 31, 1974.

13. "Conditional Order Modifying Faculty Desegregation Orders," Judge W. Arthur Garrity, U. S. District Court of Massachusetts, June 2, 1981.

14. Morgan v. Kerrigan, 530 F. 2nd 431 (1976).

15. "Boston Teachers Union's Response to 'Plantiff's' Motion," submitted to U.S. District Court of Massachusetts, A pril 19, 1978, p. 2.

16. “Boston Teachers Union's Preliminary Memorandum Regarding Reduction in Force, submitted to U.S. District Court of Massachusetts, March 4, 1981.

17. Unpublished "EEO-5" reports filed by each of the school districts with EEOC.

18. H. C. Katz, The Boston Teachers Union and the Desegregation Process, in Public Sector Labor Relations, David Lewin et al. (eds), 2nd edition, Horton and Daughters Publishing, Inc., Glen Ridge, New Jersey, 1981.

Harry Katz is an Associate Professor of Industrial Relations at the M.I.T. Sloan School of Management. His primary current research interests concern public sector labor relations and collective bargaining in the automobile industry.

Direct reprint requests to:

Harry C. Katz

Professor of Industrial Relations

Sloan School of Management

Massachusetts Institute of Technology

50 Memorial Drive

Cambridge, MA 02139 